NASA Contractor Report 3815

Residual Strength of Five

Boron/Aluminum Laminates

With Crack-Like Notches

After Fatigue Loading

R. A. Simonds

CONTRACT NAS1-17100

JULY 1984

\title{
N/SN
}



NASA Contractor Report 3815

\section{Residual Strength of Five Boron/Aluminum Laminates With Crack-Like Notches After Fatigue Loading}

R. A. Simonds

Virginia Polytechnic Institute and State University Blacksburg, Virginia

Prepared for

Langley Research Center under Contract NAS1-17100

\section{N/Sก}

National Aeronautics and Space Administration

Scientific and Technical Information Branch 


\section{INTRODUCTION}

A study by Poe and Sova, Ref. 1, establishes a relationship between "damage", in the form of a crack-like slit machined perpendicular to the load directions and in the center of a Boron/Aluminum tensile specimen, and the specimen's static fracture strength. The series of tests included specimens of five different B/Al laminate configurations, several slit lengths and several specimen widths. Thus, the strength of "damaged" specimens could be compared with the strength of "undamaged" specimens determined by prior experiments, Ref. 2. The present study seeks to amplify that knowledge by adding fatigue damage to the ends of the slits. The specimens are fatigued at a level high enough that significant fatigue damage develops, yet not at such a high level that the specimen fails in fatigue before 100,000 cycles. The present study then seeks to document the fatigue damage and to see what the effect of the fatigue damage is on the residual strength of the specimen.

\section{MATERIAL AND SPECIMENS}

The B/Al laminates were made by diffusion bonding .006 inch diameter boron fibers and 6061 aluminum foil. The laminates were tested without any subsequent heat treatment. The laminate orientations were $[0]_{6 \mathrm{~T}}, \quad\left[\mathrm{O}_{2} / \pm 45\right]_{S}, \quad\left[ \pm 45 / 0_{2}\right]_{S}, \quad[0 / \pm 45]_{S}$, and $[ \pm 45]_{2 s}$. The volume fractions were 50 percent for the $[0]_{6 T}$ laminate and 45 percent for the cross-plied laminates. Fatigue/fracture, fracture and tensile specimens were cut from each sheet of material. Results of the tensile tests were reported in Ref. 2 and some of the average tensile results are shown in Table I for convenience. The results are for specimens .75 inches wide 
except for the $[ \pm 45]_{2 s}$ laminate where the results are for a 4.00 inch wide specimen. There is a significant width effect for the $[ \pm 45]_{2 s}$ laminate so the $[ \pm 45]_{2 s}$ data included in Table $I$ is for the same width specimens as the specimens included in the present study. No appreciable width effect was found for the other laminate orientations.

The fatigue/fracture specimens were all 4.00 inches wide. Cracklike slits were inachined into the center of each specimen with an electrical-discharge process. The slits were perpendicular to the loading direction and had lengths of 0.40 inches, 1.20 inches, and 2.00 inches. Figure 1 shows a sketch of the fatigue/fracture specimens that identifies fiber angles and shows the location of the grips.

The fracture strengths of the various types of specimens were known prior to the present study from Ref. 1. For convenience those results are duplicated here in Table II.

\section{TEST PROCEDURES AND EQUIPMENT}

The specimens were tested in a hydraulically actuated, closed loop, servo controlled testing machine. The load, which was measured by a conventional load cell, was used for the feedback signal. For the fatigue portion of the tests, a function generator produced a sinusoidal command signal of $10.0 \mathrm{~Hz}$. The testing machine was set so that the maximum cyclic load was a certain percentage of the average static failure load for each slit length and laminate orientation as deterinined in Ref. 1. The ratio of minimum to maximum stress was generally equal to $\mathbf{0 . 0 5}$. Most of the specimens were fatigued for 100,000 load cycles. The residual strength fracture tests were accomplished on the same 
testing machine by resetting the function generator to output a slow linear ramp command signal so that the specimen failed in about 2 minutes.

Many of the specimens were radiographed after and sometimes during the fatigue portion of the testing in order to determine the damage caused by the fatigue loading. The radiographs were made with an industrial-type "soft" $X$-ray machine with a 0.010 inch beryllium window and a tungsten target. The voltage and current were set for $50 \mathrm{kV}$ and $20 \mathrm{~mA}$, respectively. The window of the $X$-ray tube was 12 inches from the specimen, and a high-resolution photographic plate was mounted directly on the opposite side of the specimen. The exposure time for each radiograph was 12 minutes.

A few specimens were destructively examined after the fatigue portion of the testing instead of being fracture tested. Typically, pieces were cut out of the specimen from the vicinity of the ends of the slits, and then leached in a sodium-hydroxide solution to enhance cracks in the aluminum matrix, remove the matrix and expose the fibers, or to remove entire plies and expose the fibers of the underlying plies. The amount of material removed was dependent on the amount of time the piece was submerged in the solution. The leached pieces could then be examined in a scanning electron microscope.

\section{RESULTS AND DISCUSSION}

The results of all of the tests that were run are summarized in Table II. Figure 2 compares the fracture strength of the fatigued specimens with the average strength of the specimens from Ref. 1 that 
were fractured without any prior fatigue loading. The percentage of the static failure load that was used for the fatigue loading is indicated for each data point, and any specimen that was not cycled 100,000 times is indicated as well. More than one percentage indicates two or more specimens whose post-fatigue strength was the same. The graphs indicate that the difference in strength between the unfatigued specimens of Ref. 2 and the fatigued specimens of the present study are relatively insignificant. This happened even though substantial damage often developed in the fatigued specimens as discussed below.

\section{Fiber Damage}

With the exception of one of the laminates, the preponderance of fiber damage occurred in the $\pm 45^{\circ}$ plies rather than in the $0^{\circ}$ plies. Figure 3 shows radiographs taken of the slit ends of specimen 04022 , which was a $[0]_{6 T}$ laminate, after the specimen was fatigued for 100,000 cycles at $35 \%$ of the static fracture strength. The few fibers that are broken, as indicated by the gaps in the white line images of the tungsten fiber cores, all occur in the immediate vicinity of the ends of the slit. Specimen 04022 experienced a very slight increase in fracture strength over the average unfatigued strength.

Figure 4 is a radiograph of the ends or the slit of specimen 43032 which is a $\left[0_{2} / \pm 45\right]_{s}$ laminate. Negligible damage to the fibers can be seen in the radiographs. Figure 5 shows the first and second plies, both $0^{\circ}$ of the same specimen after matrix removal, as viewed in the scanning electron microscope. Zero degree fibers, except those actually cut by the slit, are intact. However, the $45^{\circ}$ fibers, as shown in Fig. 6, show extensive damage that was not apparent in the 
radiographs. The $45^{\circ}$ fibers appear to have split and washed away during matrix removal.

Figures 7 and 8 show similar damage to $45^{\circ}$ fibers and $0^{\circ}$ fibers respectively in specimen 58032. This specimen is a $\left[ \pm 45 / 0_{2}\right]_{S}$ laminate giving it equal proportions or $45^{\circ}$ and $0^{\circ}$ fibers as specimen 43032 , but a different stacking sequence. Figure 7 indicates a detail of the $45^{\circ}$ fibers showing the type of damage they suffer in the fatigue loading. Figure 8 shows the relatively undamaged $0^{\circ}$ fibers toward the center of the specimen.

Laminate $[0 / \pm 45]_{S}$ was the only one of the five laminates to show significant damage to the $0^{\circ}$ fibers as a result of the fatigue loading. Some of the radiographs of specimens of this laminate show broken $0^{\circ}$ fibers as far as eight fibers away from the ends of the slit. Figure 9 is a radiograph of specimen 31022 showing broken $0^{\circ}$ fibers as well as broken $45^{\circ}$ fibers. Figure 10 shows the results of fatiguing specimen 31012 for 100,000 cycles at $70 \%$ of the estimated failure load, sectioning the specimen, then leaching the matrix away with sodium hydroxide to expose broken $0^{\circ}$ fibers. Further leaching reveals extensively damaged $45^{\circ}$ fibers (Fig. 11) as seen in the other laminates containing $45^{\circ}$ fibers.

Damage to fibers in the $[ \pm 45]_{2 s}$ laminates appears to be similar to the damage to $45^{\circ}$ fibers in the other laminates even though there are no accompanying $0^{\circ}$ fibers. Figure 12 shows the results of fatiguing specimen 13013 for 100,000 cycles to $70 \%$ of its average unfatigued static strength. A portion of the specimen taken from the area of one end of the slit was leached in sodium hydroxide to remove the top three plies to reveal the middle two plies, both parallel to one another, and 
portions of the underlying 6 th ply. The fibers are extensively damaged and many of the broken pieces have simply fallen away from the section once the matrix was dissolved away.

Unpublished work by C. C. Poe, Jr. of NASA Langley Research Center indicates that the $45^{\circ}$ fibers are subjected to large tensile stresses transverse to the fibers. Thus, the $45^{\circ}$ fibers could have broken because their transverse fatigue strength is low. The asymmetrical pattern of damage in Figs. $6,7,11$, and 12 is consistent with such a failure mode. Similar fiber damage was noted in Refs. 4 and 5 .

\section{Matrix Damage}

Matrix damage in the boron/aluminum laminates subjected to fatigue loading appeared to take two forms: cracks in the $0^{\circ}$ plies which started at the ends of the slits, grew parallel to the $0^{\circ}$ fibers, through the specimen thickness, and towards the grips with increasing numbers of cycles; cracks in the $45^{\circ}$ plies originating at split $45^{\circ}$ fibers. In addition, some cracks were observed between $0^{\circ}$ plies and adjacent $45^{\circ}$ plies. In the $[0]_{6 T}$ laminates, cracks developed very quickly at the ends of the slits and grew very quickly along the $0^{\circ}$ fibers towards the grips. The matrix cracks in the $[0]_{6 T}$ specimens grew so quickly that the $[0]_{6 T}$ specimens were fatigued at lower percentages of their static fracture strengths. Figure 13 is a photograph of specimen 04022 showing that the fatigue cracks grew from the ends of the slit and then that the specimen fractured at the ends of the fatigue cracks rather than at the ends of the slit. Pencil marks were made on the surface of the specimen at the visible ends of the fatigue cracks after the fatigue portion of the testing. During the subsequent 
fracture testing, the specimen fractured from the ends of the fatigue cracks rather than from the ends of the original slit. This behavior is in agreement with the predictions of shear lag analysis (Ref. 3). At fracture, there was some additional cracking in the $0^{\circ}$ directions as there was in the fracture testing of unfatigued $[0]_{6 T}$ specimens with slits (Ref. 1).

Figure 14 is a cross-section of specimen $43032,\left[0_{2} / \pm 45\right]_{S}$, slightly above the slit. The section has been etched with sodium-hydroxide to enhance the matrix cracks. It shows cracks at the end of the slit in the $0^{\circ}$ plies, between the $0^{\circ}$ and $+45^{\circ}$ plies, and in the $45^{\circ}$ plies.

Specimen $58032,\left[ \pm 45 / 0_{2}\right]$, Fig. 15, shows virtually identical matrix cracking even though the stacking sequence is different. Figure 15 also shows that surface cracks occur coincident with fiber splits in the first $45^{\circ}$ ply.

Fatiguing of $[0 / \pm 45]_{S}$ laminates with slits does not appear to create a single dominating matrix crack in the $0^{\circ}$ plies as it does in the other laminates containing $0^{\circ}$ plies. Instead, several cracks appear between adjacent $0^{\circ}$ fibers as can be seen in Fig. 16. Note that the matrix cracks in the $0^{\circ}$ plies are between the fibers as opposed to connected with split fibers as in the $45^{\circ}$ plies.

Matrix damage to $[ \pm 45]_{2 s}$ laminates took the form of matrix damage in the $45^{\circ}$ plies as in other laminates: coincident with splits in the $45^{\circ}$ fibers. 
SUMMARY OF RESULTS

Boron/Aluminum specimens containing crack-like slits in their centers perpendicular to the loading direction were fatigued. The fatigue loading was sufficient to cause damage to occur at the ends of the slits but not so high as to cause the specimens to fail in fatigue. The specimens were radiographed in an effort to determine what the resulting damage was. Broken fibers are fairly easy to detect in the radiographs, however matrix damage is virtually indiscernable radiographically. In a few cases, specimens were sectioned and examined microscopically in order to verify the existence of the broken fibers as seen in the radiographs and in order to determine what the matrix damage was. Fatigue damage at the ends of the slits takes the following forms:

1. Extensively broken $45^{\circ}$ fibers in all of the laminates containing $45^{\circ}$ fibers.

2. In specimens in which at least $50 \%$ of the plies are $0^{\circ}$ plies, there are cracks in the matrix in the $0^{\circ}$ direction in the $0^{\circ}$ plies starting at the ends of the slits and growing towards the grips.

3. Matrix cracking in the $45^{\circ}$ plies associated with split and/or broken $45^{\circ}$ fibers.

In addition, there are some broken $0^{\circ}$ fibers in the $[0 / \pm 45]_{S}$ laminate specimens and in those specimens containing both $0^{\circ}$ plies and $45^{\circ}$ plies there is a tendency of the matrix to crack between a $0^{\circ}$ ply and an adjacent $45^{\circ}$ ply.

In spite of the above damage, there is virtually no change in the strength of a fatigued boron/aluminum specimen containing a slit in the center compared to a similar specimen without fatigue. 
Acknowledgments

The author would like to acknowledge the support of the NASA Langley Research Center through NASA Contract NAS1-17100. Sincere appreciation is extended to C. C. Poe, Jr. of NASA Langley for his encouragement and helpful discussions. Sincere appreciation is also extended to B. I. Wengert of VPI \& SU for typing the report.

\section{References}

1. Poe, C. C., Jr. and Sova, J. A.: Fracture Toughness of Boron/Aluminum Laminates with Various Proportions of $0^{\circ}$ and $\pm 45^{\circ}$ Plies. NASA TP-1707, 1980.

2. Sova, J. A. and Poe, C. C. Jr.: Tensile Stress Strain Behavior of Boron/Aluminum Laminates. NASA TP-1117, 1978.

3. Dharani, L. R., Jones, W. F. and Goree, J. G.: Mathematical Modeling of Damage in Unidirectional Composites. Engineering Fracture Mechanics, Vol. 17, No. 6, 1983.

4. Johnson, W. S.: Mechanisms of Fatigue Damage in Boron/Aluminum Composties. Damage in Composite Materials, ASTM STP 775, American Society for Testing and Materials, 1982, pp. 83-102.

5. Menke, G. D. and Toth, I. J.: The Time Dependent Mechanical Behavior of Metal Matrix Composites. AFML-TR-71-102, Air Force Materials Laboratory, Sept. 1971. 
Table I. Tensile Strengths of Laminates.

\begin{tabular}{|l|c|c|c|}
\hline Laminate & $\begin{array}{l}\text { Laminate } \\
\text { Thickness, in. }\end{array}$ & $\begin{array}{c}\text { Specimen } \\
\text { Width, in. }\end{array}$ & $\begin{array}{c}\text { Strength, } \\
\text { ksi }\end{array}$ \\
\hline$[0]_{6 \mathrm{~T}}$ & .0420 & 0.75 & 242 \\
{$\left[0_{2} / \pm 45\right]_{\mathrm{S}}$} & .0586 & 0.75 & 116 \\
{$\left[ \pm 45 / 0_{2}\right]_{\mathrm{S}}$} & .0595 & 0.75 & 132 \\
{$[0 / \pm 45]_{\mathrm{S}}$} & .0437 & 0.75 & 84.3 \\
{$[ \pm 45]_{2 \mathrm{~S}}$} & .0600 & 4.00 & 32.0 \\
\hline
\end{tabular}


Laminate: $\quad[0]_{6 T}$

\begin{tabular}{|c|c|c|c|c|c|}
\hline Spec. no. & $\begin{array}{l}\text { Slit } \\
\text { length, in. }\end{array}$ & $\begin{array}{l}\text { Average static } \\
\text { strength, ksi }\end{array}$ & $\begin{array}{l}\text { Fatigue stress, } \mathrm{ksi} \\
(\% \text { static strength) }\end{array}$ & $\begin{array}{l}\text { No. of } \\
\text { cycles }\end{array}$ & $\begin{array}{l}\text { Post fatgue static strength, ksi } \\
\text { (\% unfatigued static strength) }\end{array}$ \\
\hline 03012 & 0.4 & 114 & $57.0(50)$ & $25 \mathrm{~K}$ & (125) \\
\hline 04012 & & & $45.6(40)$ & $100 \mathrm{~K}$ & (106) \\
\hline 05012 & & & $45.6(40)$ & $100 \mathrm{~K}$ & (111) \\
\hline 06012 & & & $57.0(50)$ & $100 \mathrm{~K}$ & $132 \quad(116)$ \\
\hline 03022 & 1.2 & 73.3 & $36.7(50)$ & $50 \mathrm{~K}$ & $99.7(136)$ \\
\hline 04022 & & & 25.7 (35) & $100 \mathrm{~K}$ & $64.9(88.5)$ \\
\hline 05022 & & & $18.3(25)$ & $100 \mathrm{~K}$ & $76.5(104)$ \\
\hline 06022 & & & $36.7(50)$ & $100 \mathrm{~K}$ & $83.0(114)$ \\
\hline 03032 & 2.0 & 56.2 & $16.9(30)$ & $100 \mathrm{~K}$ & $65.2(116)$ \\
\hline 04032 & & & $11.2(20)$ & $100 \mathrm{~K}$ & $59.5(106)$ \\
\hline 05032 & & & $16.9(30)$ & $100 \mathrm{~K}$ & 66.7 (119) \\
\hline 06032 & & & $22.4(40)$ & $100 \mathrm{~K}$ & $57.4 \quad(102)$ \\
\hline
\end{tabular}

TABLE II.- RESULTS OF FATIGUE/FRACTURE TESTS ON BORON/ALUMINUM 
Laminate: $\left[0_{2} / \pm 45\right]_{S}$

\begin{tabular}{|c|c|c|c|c|c|}
\hline Spec. no. & $\begin{array}{l}\text { Slit } \\
\text { length, in. }\end{array}$ & $\begin{array}{l}\text { Average static } \\
\text { strength, ksi }\end{array}$ & $\begin{array}{l}\text { Fatigue stress, ksi } \\
\text { (\% static strength) }\end{array}$ & $\begin{array}{l}\text { No. of } \\
\text { cycles }\end{array}$ & $\begin{array}{l}\text { Post fatigue static strength, ksi } \\
\text { (\% unfatigued static strength) }\end{array}$ \\
\hline 43012 & 0.4 & 53.9 & $43.1(80)$ & $100 \mathrm{k}$ & $51.0(96.3)$ \\
44012 & & & $32.3(60)$ & $100 \mathrm{~K}$ & $54.6(101)$ \\
45012 & & $43.1(80)$ & $100 \mathrm{~K}$ & $54.0(100)$ \\
46012 & & & $43.1(80)$ & $100 \mathrm{~K}$ & $57.8(107)$ \\
43022 & 1.2 & 37.2 & $26.8(72)$ & $100 \mathrm{~K}$ & $39.5(106)$ \\
44022 & & & $29.8(80)$ & $100 \mathrm{~K}$ & $39.8(107)$ \\
45022 & & & $37.2(100)$ & $27 \mathrm{~K}$ & Fatigue failure \\
46022 & & & $37.0(86)$ & $100 \mathrm{~K}$ & $44.6(120)$ \\
43032 & 2.0 & & $21.2(80)$ & $100 \mathrm{~K}$ & Specimen sectioned \\
44032 & & & $15.9(60)$ & $100 \mathrm{~K}$ & $27.8(105)$ \\
45032 & & & $21.2(80)$ & $100 \mathrm{~K}$ & Test failure \\
46032 & & & $21.2(80)$ & $100 \mathrm{~K}$ & $35.0(132)$ \\
& & & & & \\
\hline
\end{tabular}

TABLE II.- Continued 
Laminate: $\left[ \pm 45 / 0_{2}\right]_{S}$

\begin{tabular}{|c|c|c|c|c|c|}
\hline Spec. no. & $\begin{array}{l}\text { Slit } \\
\text { length, in. }\end{array}$ & $\begin{array}{l}\text { Average static } \\
\text { strength, ksi }\end{array}$ & $\begin{array}{l}\text { Fatigue stress, ksi } \\
\text { (\% static strength) }\end{array}$ & $\begin{array}{l}\text { No. of } \\
\text { cycles }\end{array}$ & $\begin{array}{l}\text { Post fatigue static strength, ksi } \\
\text { (\% unfatigued static strength) }\end{array}$ \\
\hline 58012 & 0.4 & 58.8 & $47.0(80)$ & $100 \mathrm{~K}$ & Specimen sectioned \\
59012 & & & $47.0(80)$ & $100 \mathrm{~K}$ & $53.4(90.8)$ \\
58022 & 1.2 & 37.1 & $29.7(80)$ & $100 \mathrm{~K}$ & $37.0(99.7)$ \\
59022 & & & $26.0(70)$ & $100 \mathrm{~K}$ & $40.1(108)$ \\
58032 & 2.0 & 26.5 & $15.9(60)$ & $100 \mathrm{~K}$ & Specimen sectioned \\
59032 & & & $21.2(80)$ & $100 \mathrm{~K}$ & $27.5(104)$ \\
& & & & & \\
\hline
\end{tabular}

TABLE I1.- Continued 
Laminate: $[0 / \pm 45]_{S}$

\begin{tabular}{|c|c|c|c|c|c|}
\hline Spec. no. & $\begin{array}{l}\text { Slit } \\
\text { length, in. }\end{array}$ & $\begin{array}{l}\text { Average static } \\
\text { strength, ksi }\end{array}$ & $\begin{array}{l}\text { Fatigue stress, } \mathrm{ksi} \\
(\% \text { static strength) }\end{array}$ & $\begin{array}{l}\text { No. of } \\
\text { cycles }\end{array}$ & $\begin{array}{l}\text { Post fatigue static strength, } \\
\text { (\% unfatigued static strength) }\end{array}$ \\
\hline 28012 & 0.4 & 52.3 & $36.6(70)$ & $100 \mathrm{~K}$ & $52.4(100)$ \\
\hline 29012 & & & $26.2(50)$ & $100 \mathrm{~K}$ & $55.5(106)$ \\
\hline 30012 & & & $25.6(49)$ & $100 \mathrm{~K}$ & $46.3(88.5)$ \\
\hline 31012 & & & $36.1 \quad(69)$ & $100 \mathrm{~K}$ & Specimen sectioned \\
\hline 28022 & 1.2 & 34.9 & Test failure & & \\
\hline 29022 & & & $17.5(50)$ & $100 \mathrm{~K}$ & $32.9(94.3)$ \\
\hline 30022 & & & $27.9(80)$ & $37 \mathrm{k}$ & Fatigue failure \\
\hline 31022 & & & $24.4(70)$ & $100 \mathrm{~K}$ & $34.3(98.3)$ \\
\hline 28032 & 2.0 & 22.8 & $15.7(70)$ & $100 \mathrm{~K}$ & $24.5(108)$ \\
\hline 29032 & & & $11.4(50)$ & $100 \mathrm{~K}$ & $22.3(97.8)$ \\
\hline 30032 & & & $15.7(70)$ & $100 \mathrm{~K}$ & $24.3(107)$ \\
\hline 31032 & & & $15.7(70)$ & $100 \mathrm{~K}$ & $24.3(107)$ \\
\hline
\end{tabular}

TABLE II.- Continued 
Laminate: $[ \pm 45]_{2 s}$

\begin{tabular}{|c|c|c|c|c|c|}
\hline Spec. no. & $\begin{array}{l}\text { Slit } \\
\text { length, in. }\end{array}$ & $\begin{array}{l}\text { Average static } \\
\text { strength, ksi }\end{array}$ & $\begin{array}{l}\text { Fatigue stress, ksi } \\
\text { (\% static strength) }\end{array}$ & $\begin{array}{l}\text { No. of } \\
\text { cycles }\end{array}$ & $\begin{array}{l}\text { Post fatigue static strength, ksi } \\
\text { (\% unfatigued static strength) }\end{array}$ \\
\hline 13012 & 0.4 & 19.8 & $11.9(60)$ & $100 \mathrm{~K}$ & $20.3(103)$ \\
\hline 14012 & & & $15.8(80)$ & $100 \mathrm{~K}$ & $19.5(98.5)$ \\
\hline 15012 & & & $15.8(80)$ & $100 \mathrm{~K}$ & $19.3(97.5)$ \\
\hline 16012 & & & $11.9(60)$ & $100 K$ & $24.5(124)$ \\
\hline 13022 & 1.2 & 15.6 & $12.5(80)$ & $100 \mathrm{~K}$ & $13.8(88.5)$ \\
\hline 14022 & & & $10.9(70)$ & $100 \mathrm{~K}$ & $13.8(88.5)$ \\
\hline 15022 & & & $7.8(50)$ & $100 \mathrm{~K}$ & $13.5(86.5)$ \\
\hline 16022 & & & $12.5(80)$ & $100 \mathrm{~K}$ & $17.9(115)$ \\
\hline 13032 & 2.0 & 10.4 & $8.32(80)$ & $100 \mathrm{~K}$ & $10.3(99.0)$ \\
\hline 14032 & & & $8.32(80)$ & $100 K$ & $9.96(95.8)$ \\
\hline 15032 & & & $6.24 \quad(60)$ & $100 \mathrm{~K}$ & $10.0(96.2)$ \\
\hline 16032 & & & $6.24(60)$ & $100 \mathrm{~K}$ & 12.7 (122) \\
\hline
\end{tabular}

TABLE II.- Concluded. 


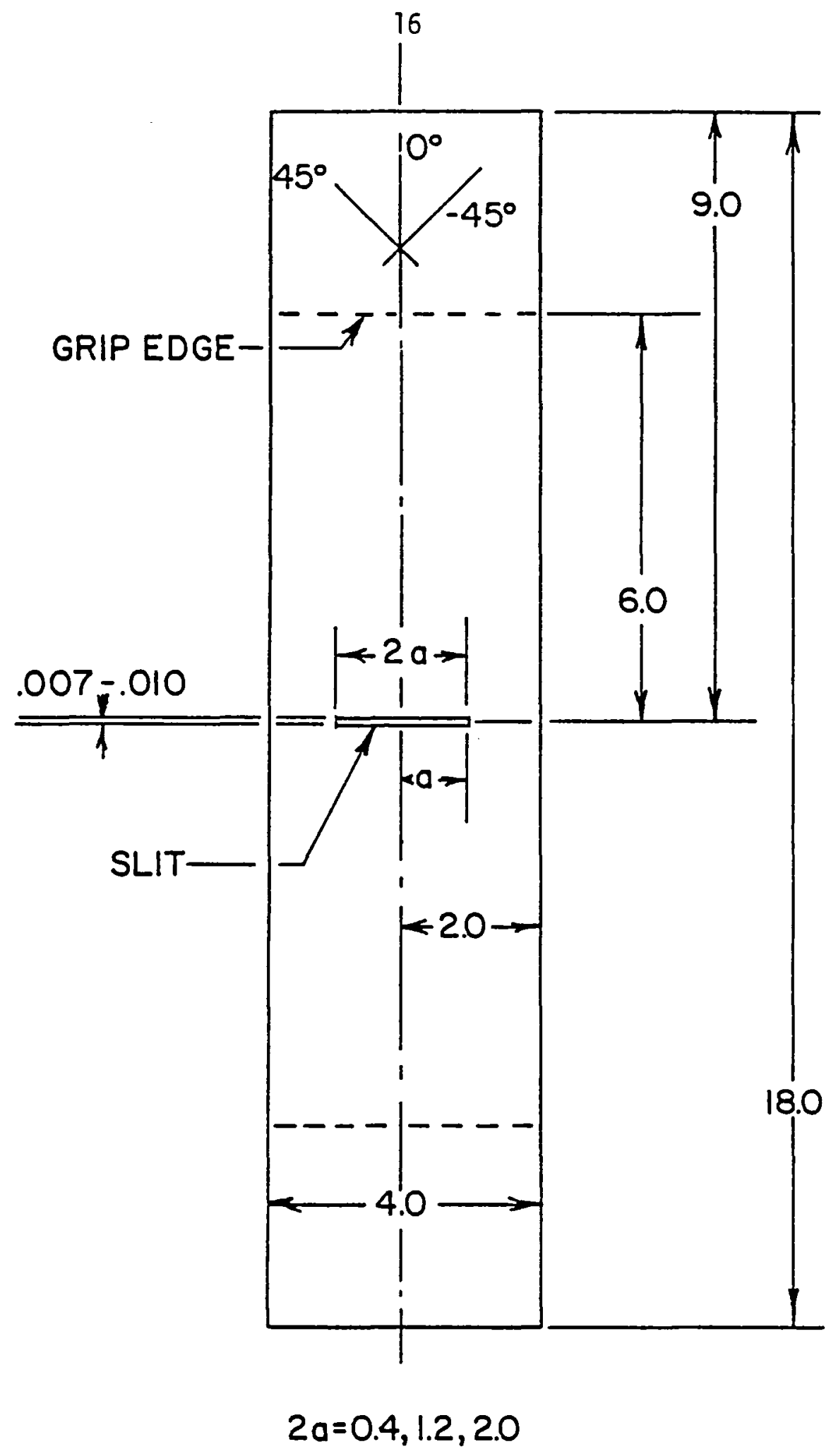

DIMENSIONS IN INCHES

Fig. 1. Specimen geometry. 


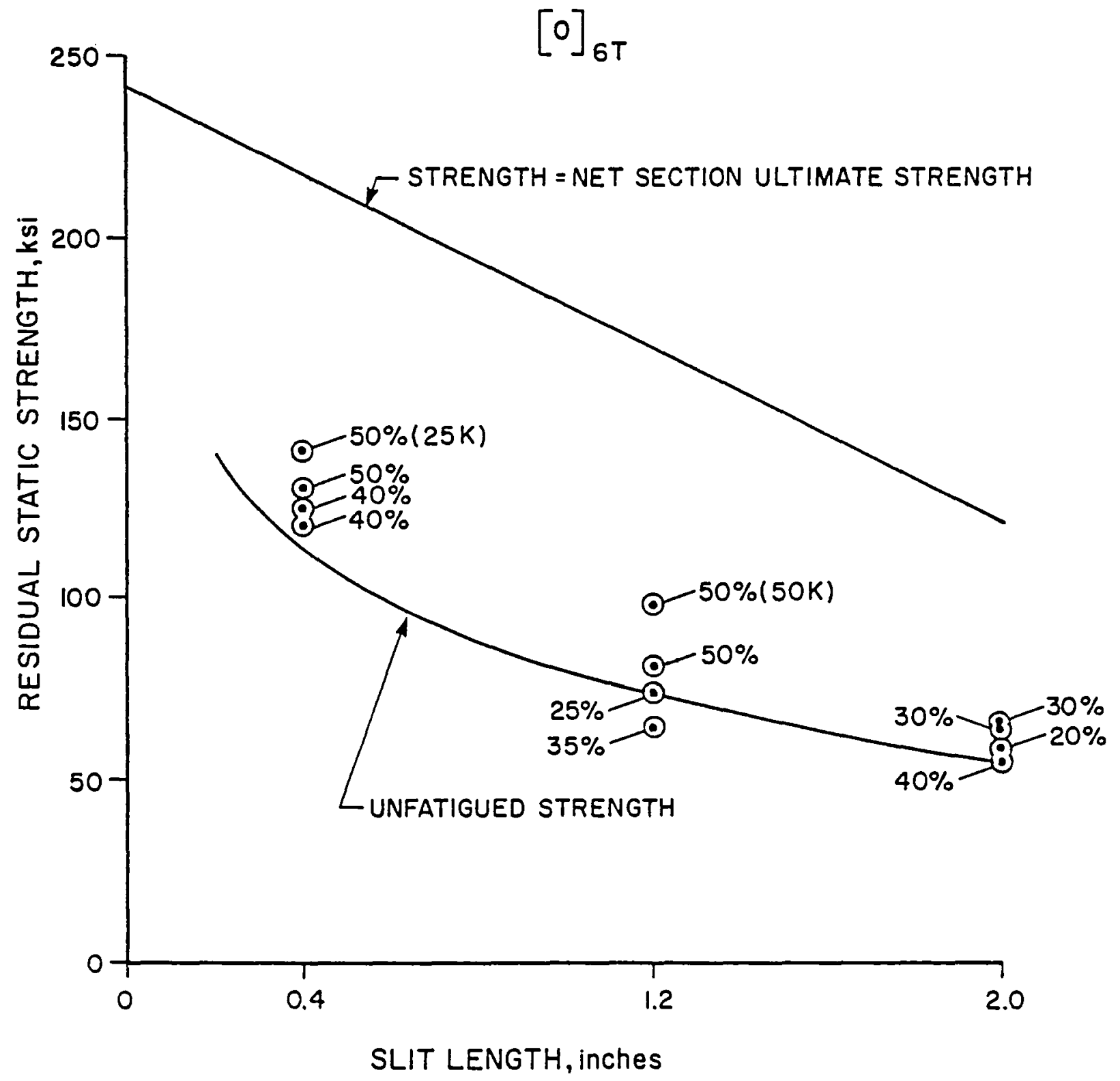

Fig. 2. Strengths of fatigued specimens compared with strengths of unfatigued specimens. 


$$
\left[\mathrm{O}_{2} / \pm 45\right]_{S}
$$

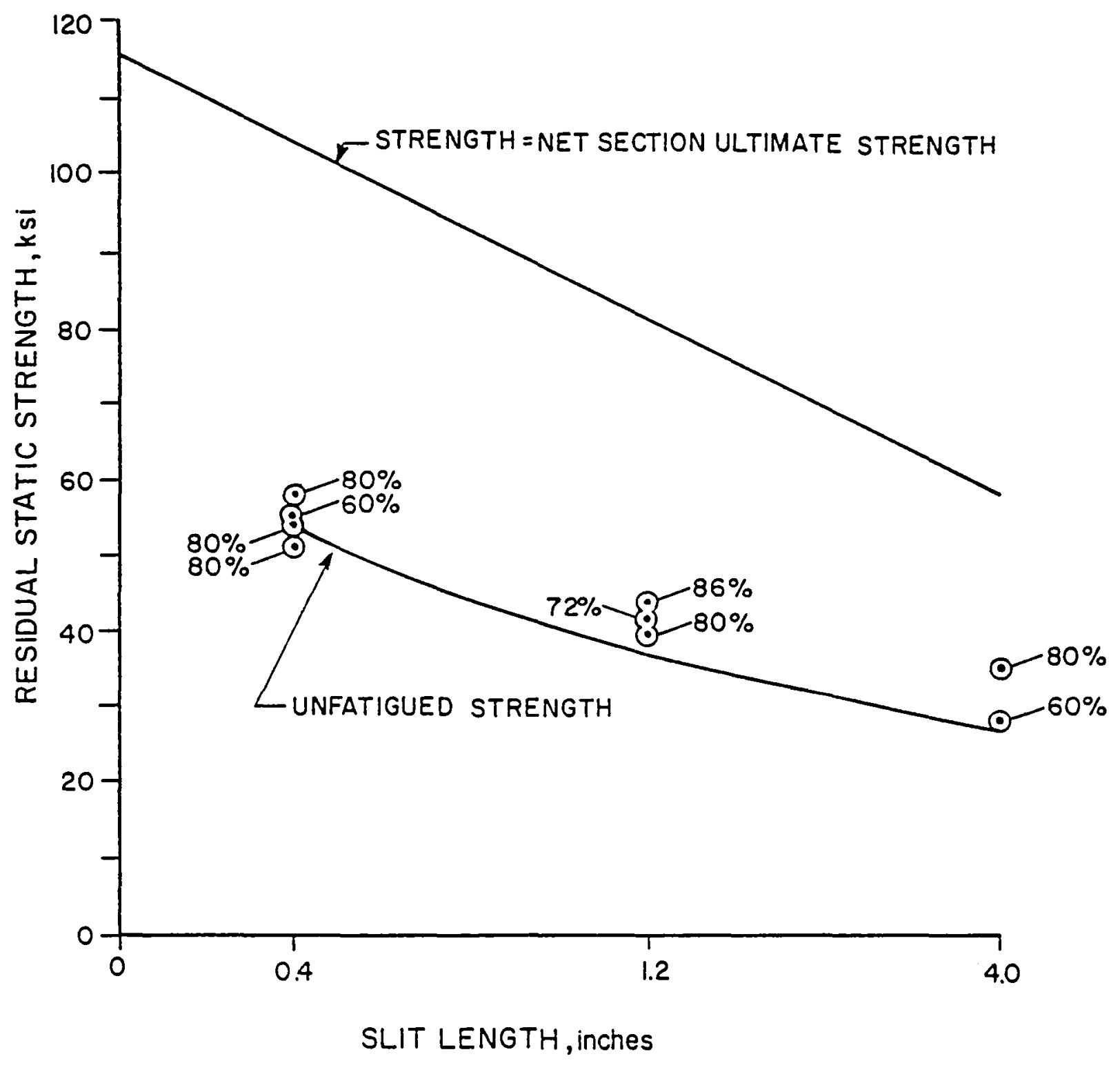

Fig. 2. (continued). 


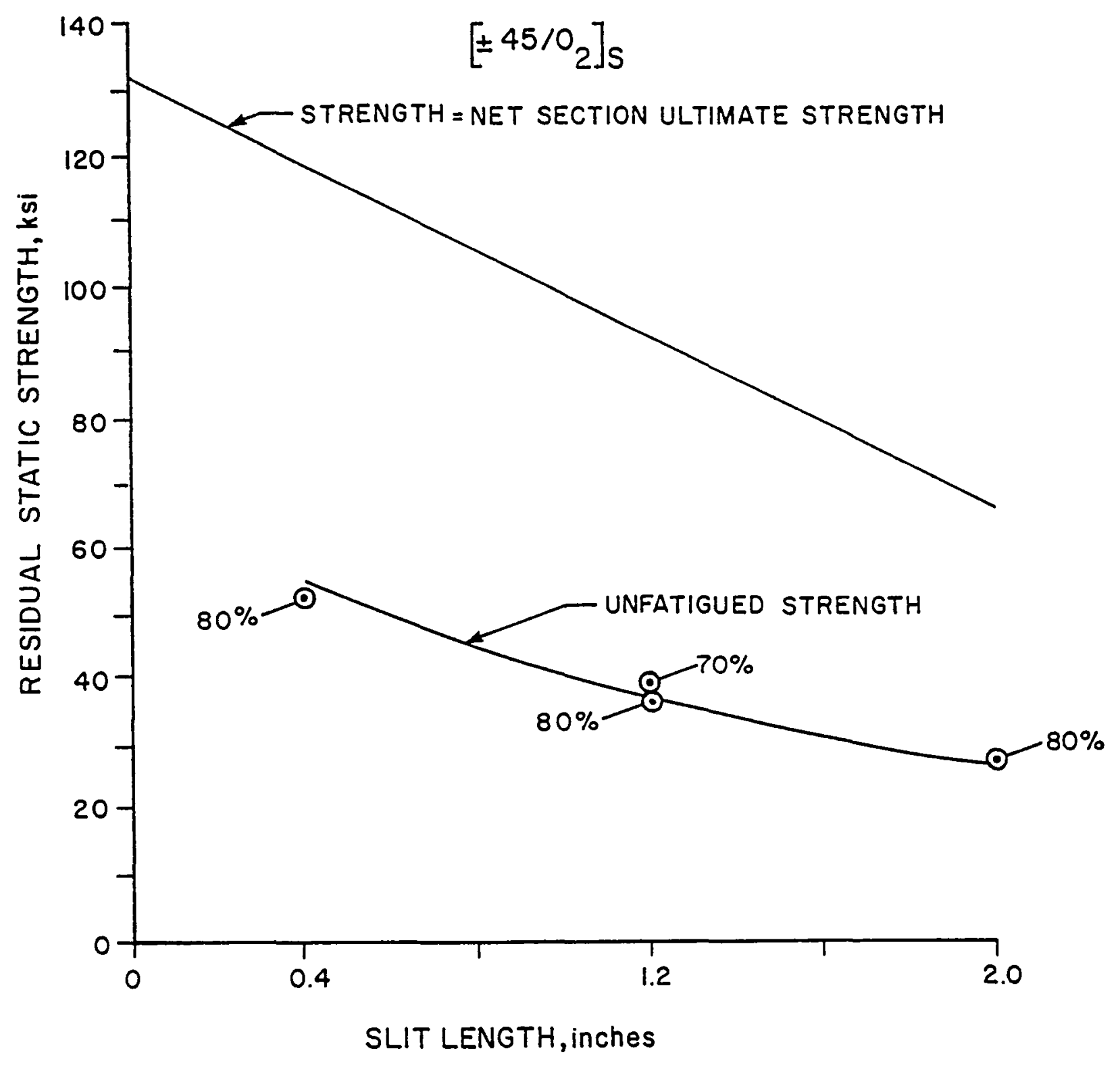

Fig. 2. (continued). 


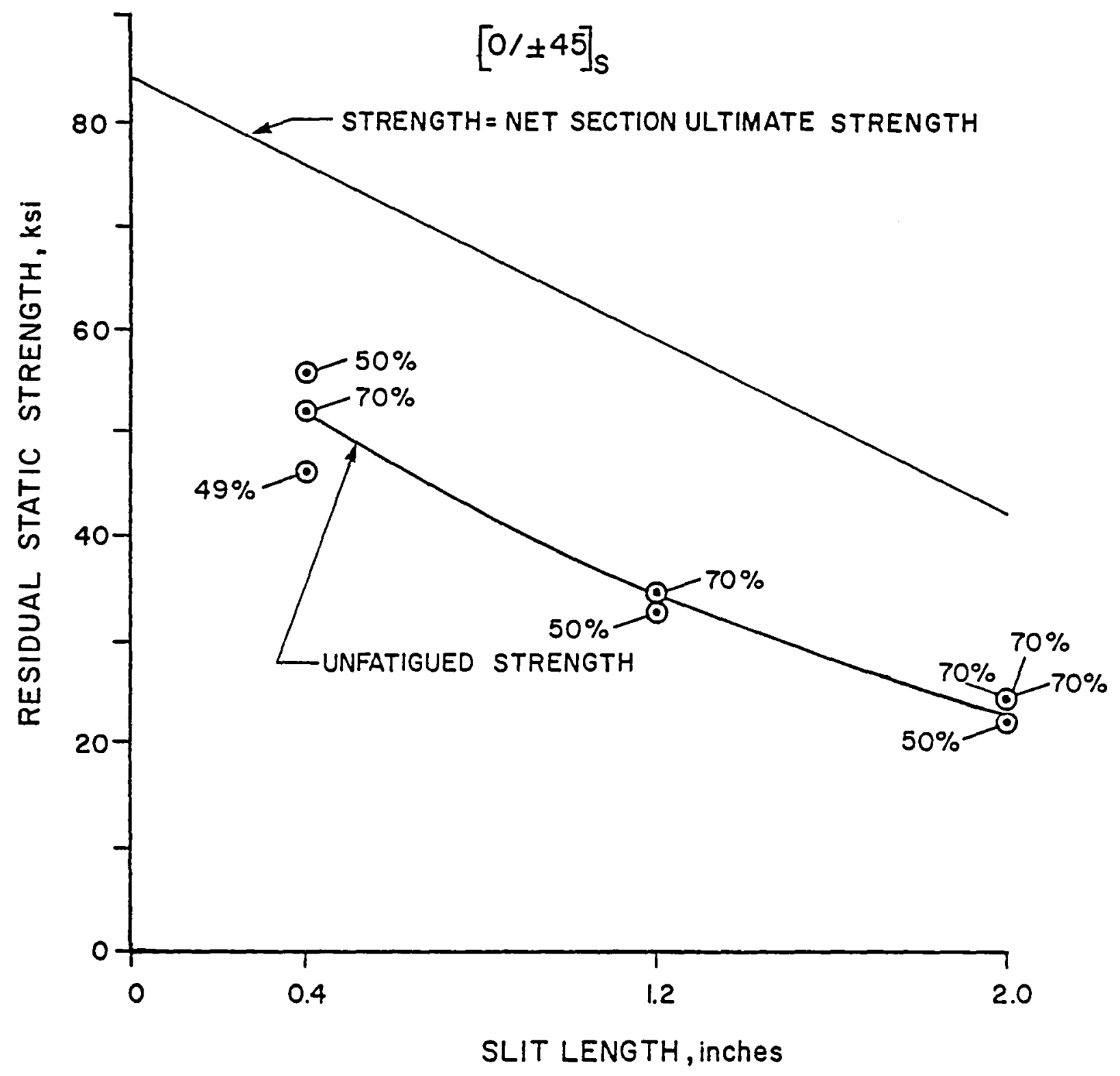

Fig. 2. (continued). 


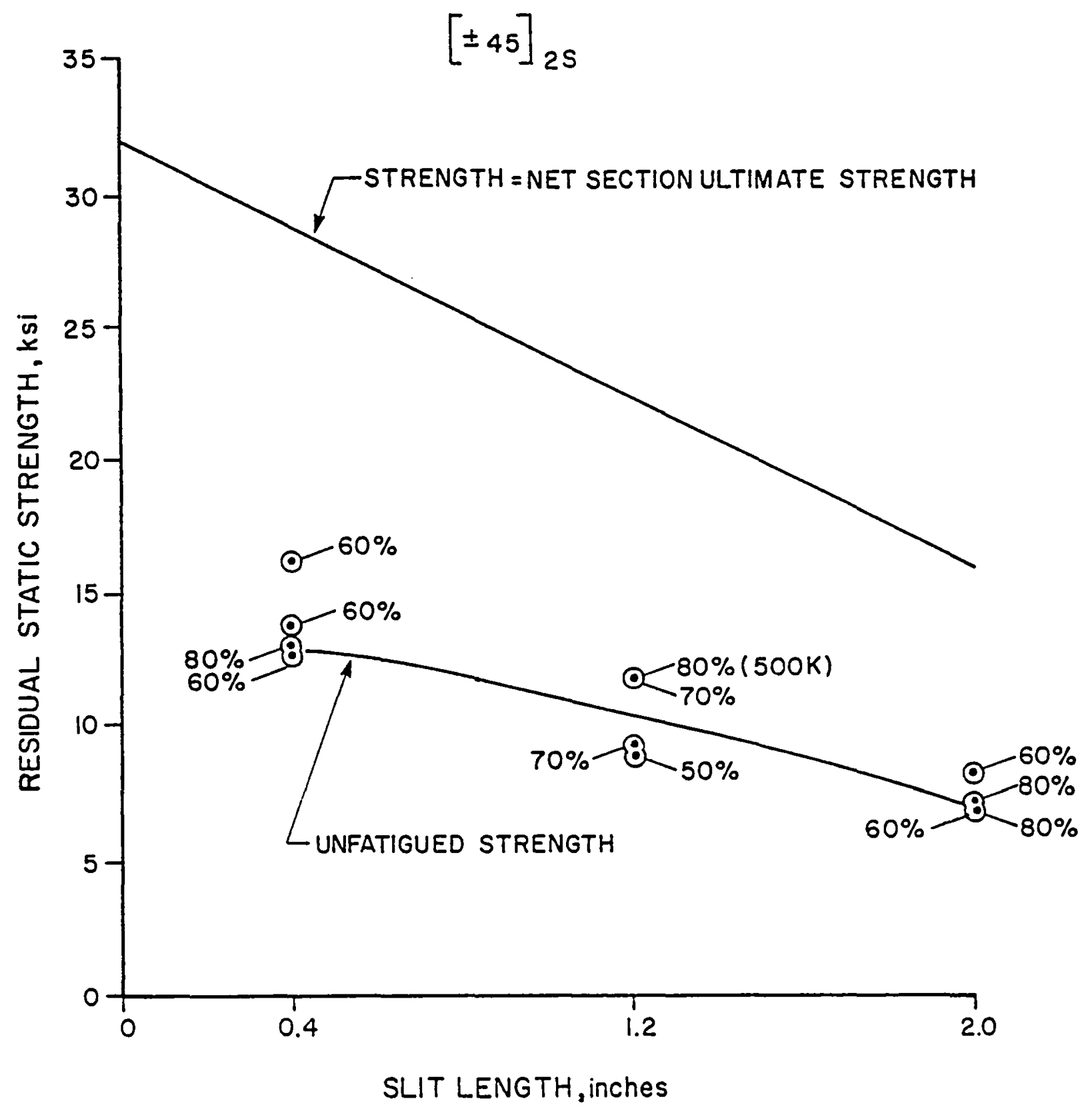

Fig. 2. (continued). 


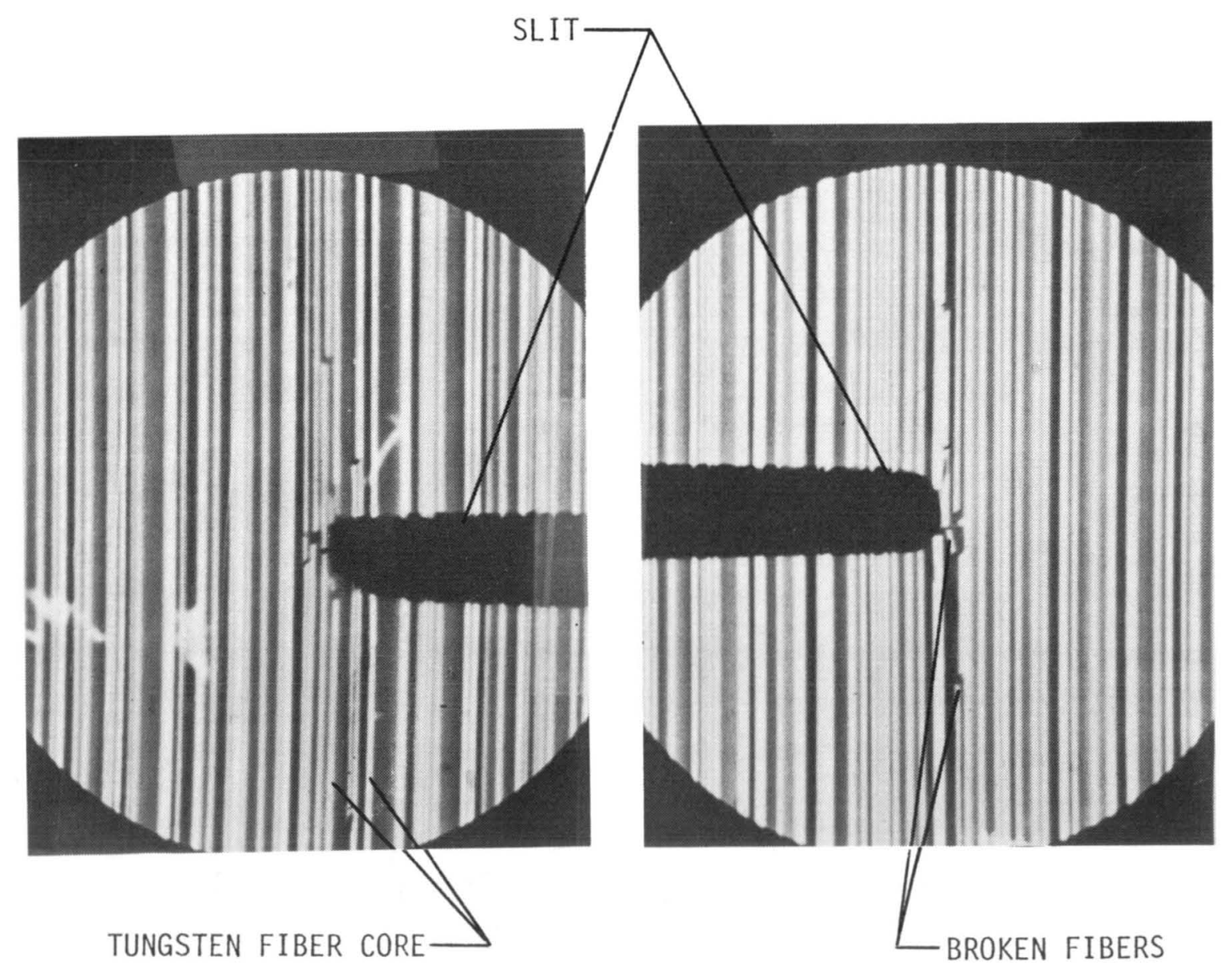

Fig. 3. Radiograph of the ends of the slit of specimen 04022 after fatiguing. 


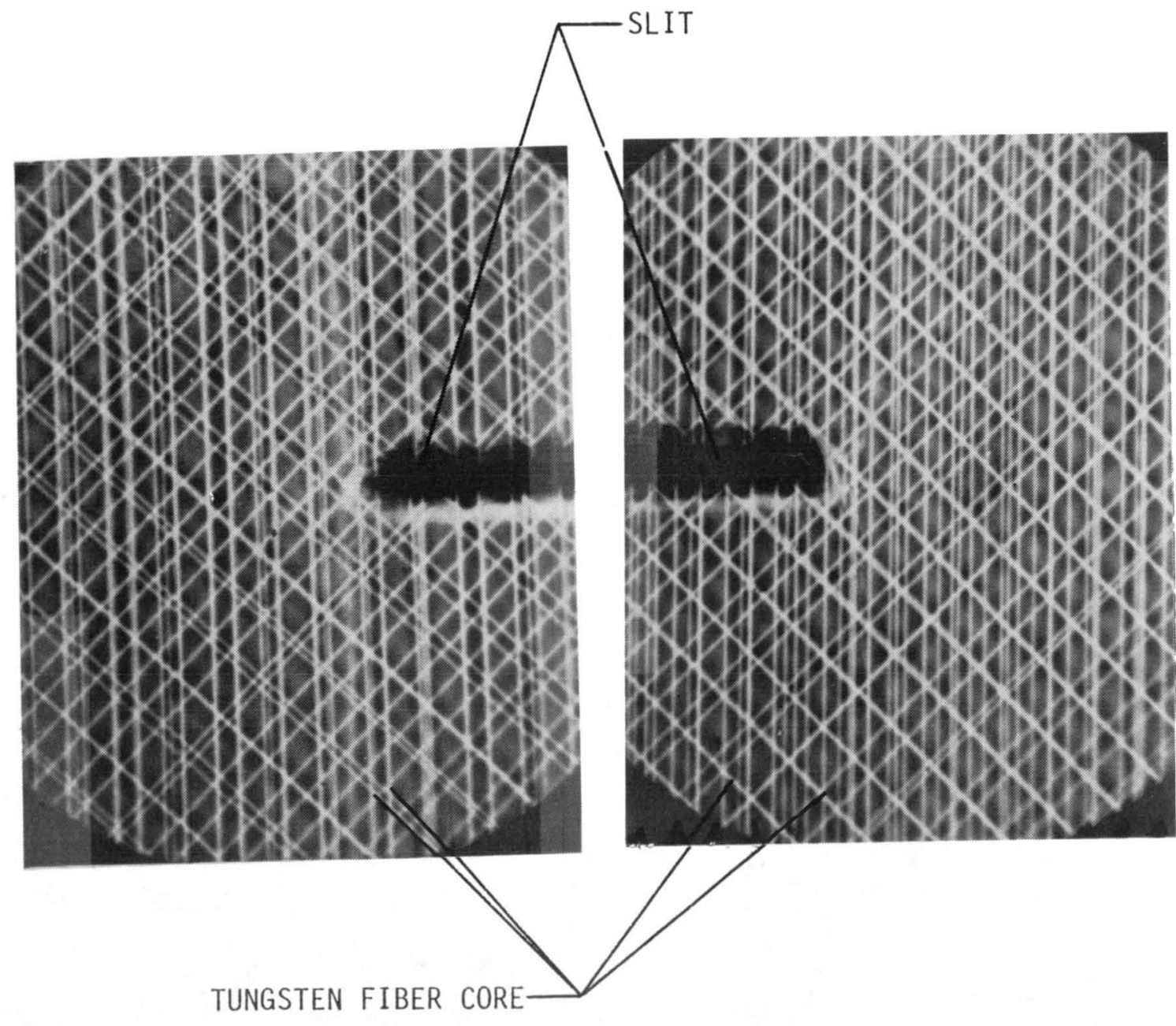

Fig. 4. Radiograph of the ends of the slit of specimen 43032 after fatiguing. 


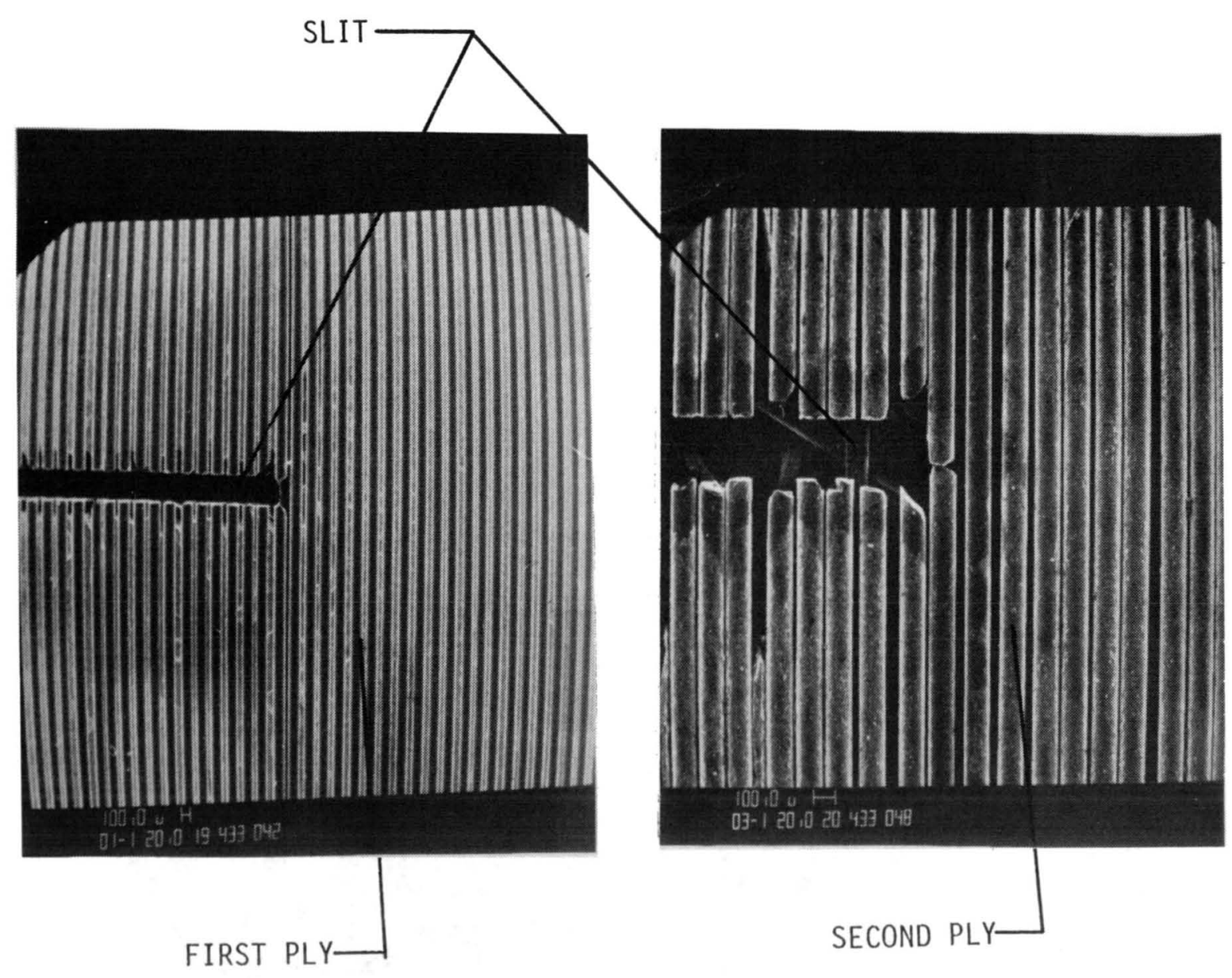

Fig. 5. Scanning electron micrograph of the first and second $0^{\circ}$ plies of specimen 43032 in the vicinity of one end of the slit after fatiguing with the matrix etched away. 


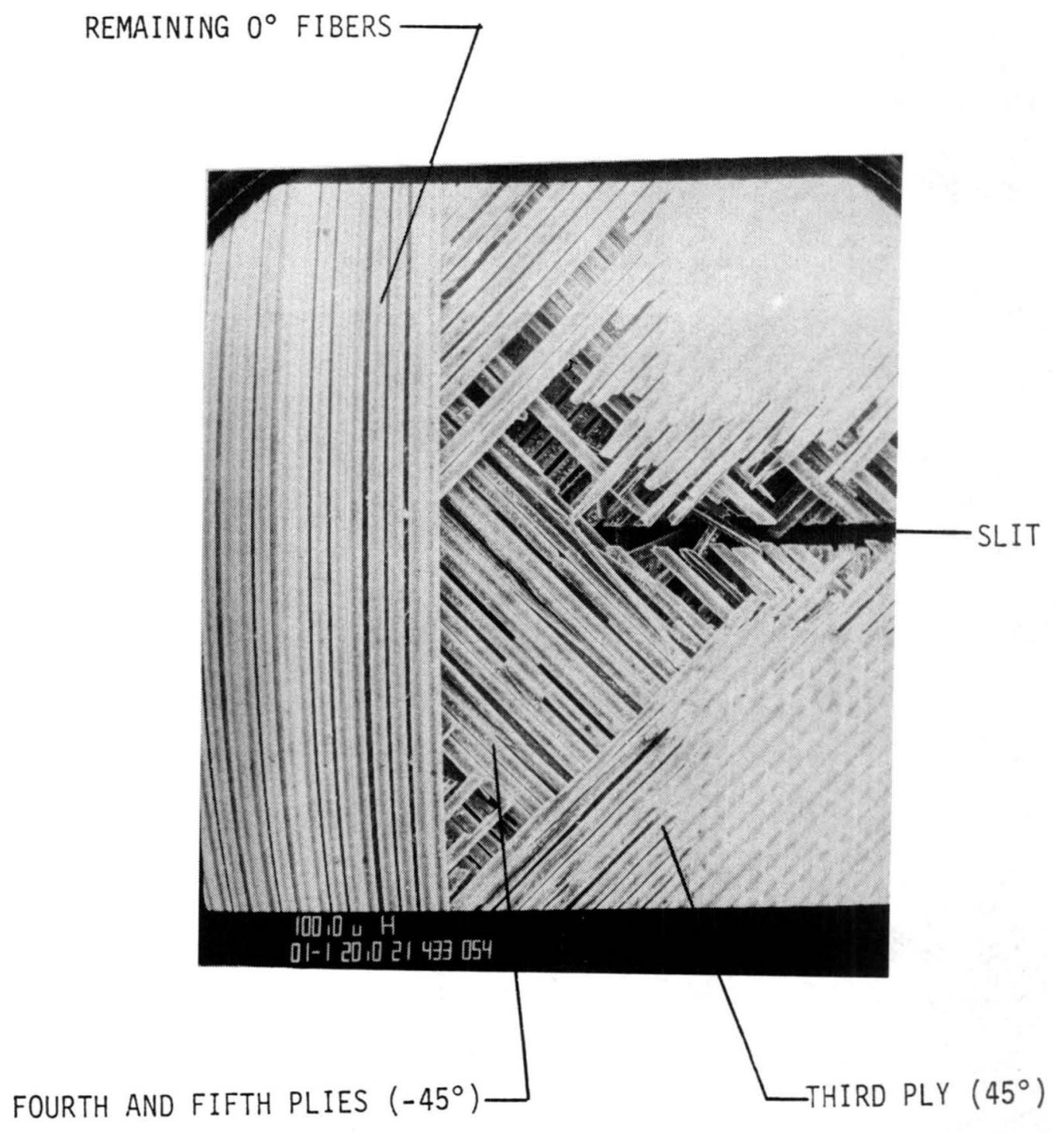

Fig. 6. Scanning electron micrograph of $45^{\circ}$ fibers of specimen 43032 . 
FIRST PLY $\left(45^{\circ}\right)$
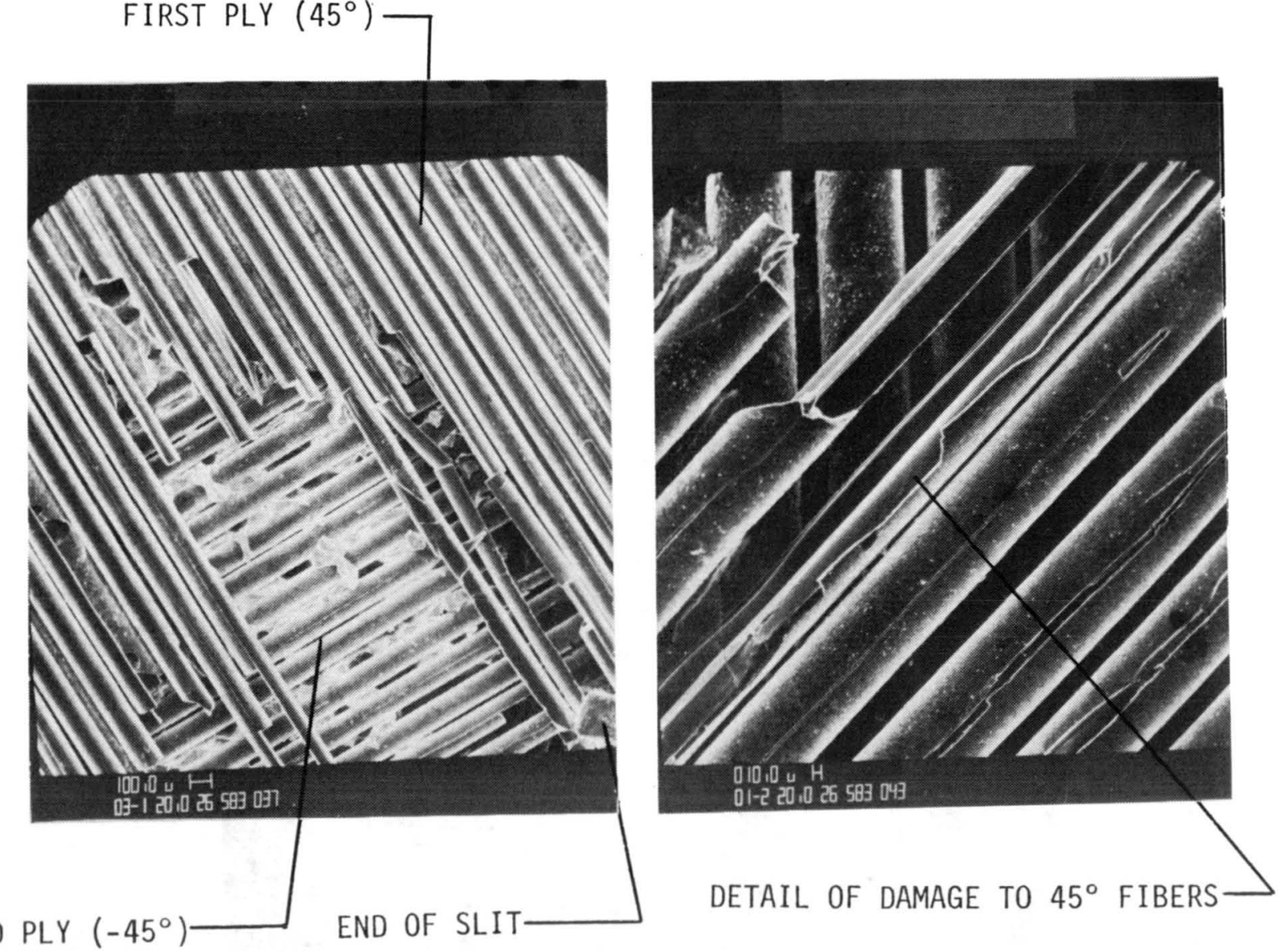

Fig. 7. Scanning electron micrograph of $45^{\circ}$ fibers of specimen 58032 with matrix removed. 


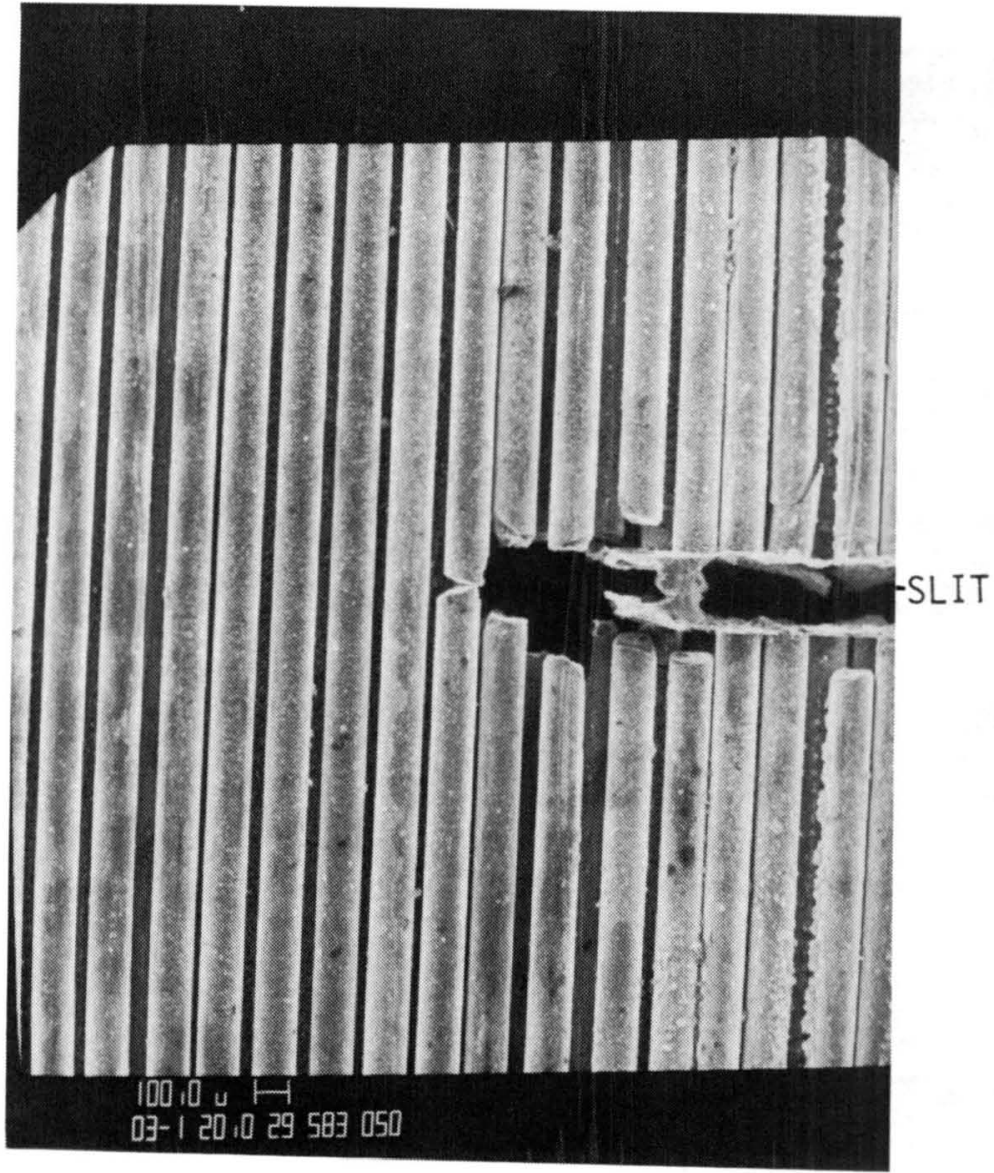

Fig. 8. $0^{\circ}$ fibers of specimen 58032 after fatiguing with matrix and overlying $45^{\circ}$ fibers removed. 


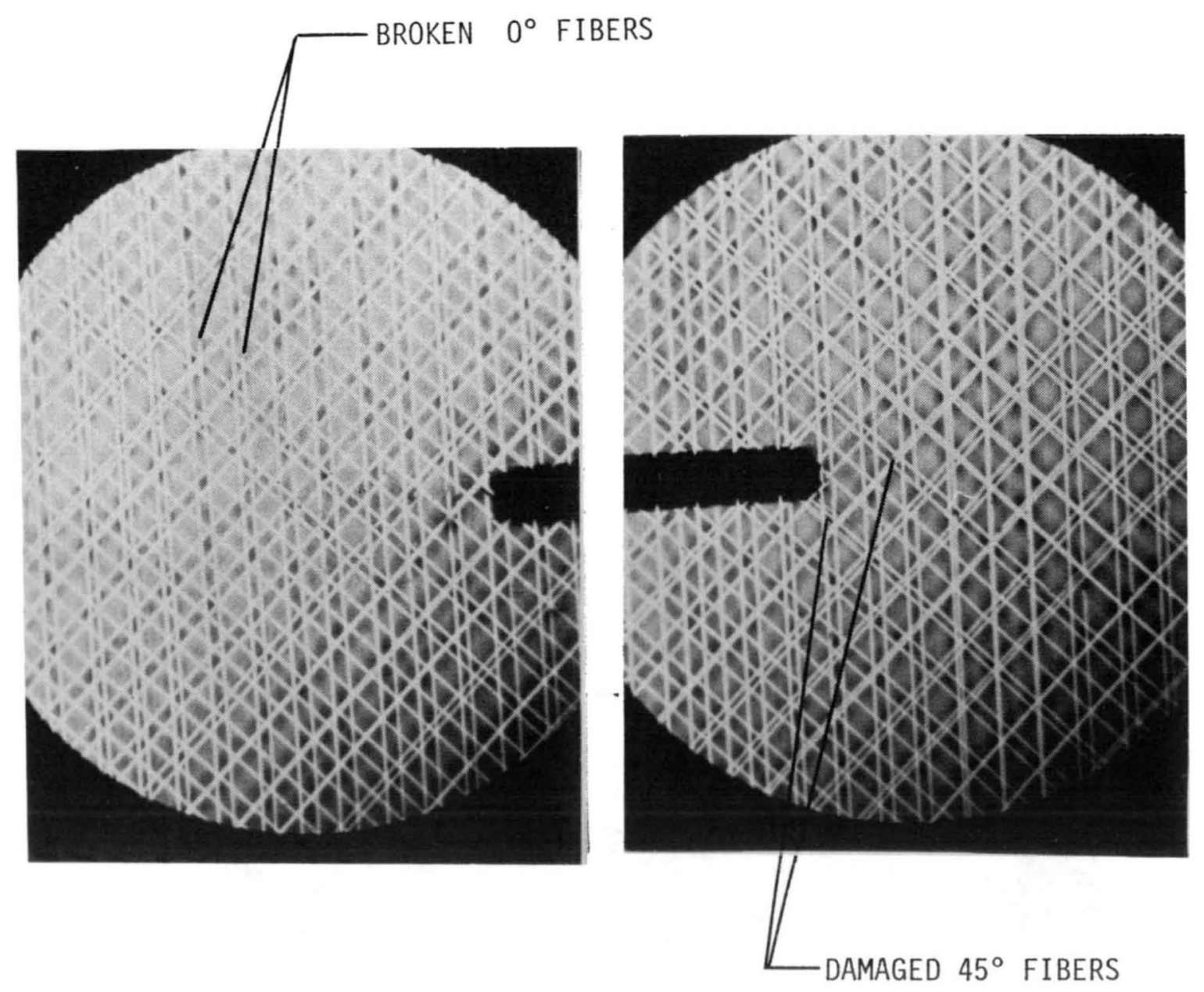

Fig. 9. Radiographs of ends of slit of specimen 31022 after fatiguing. 


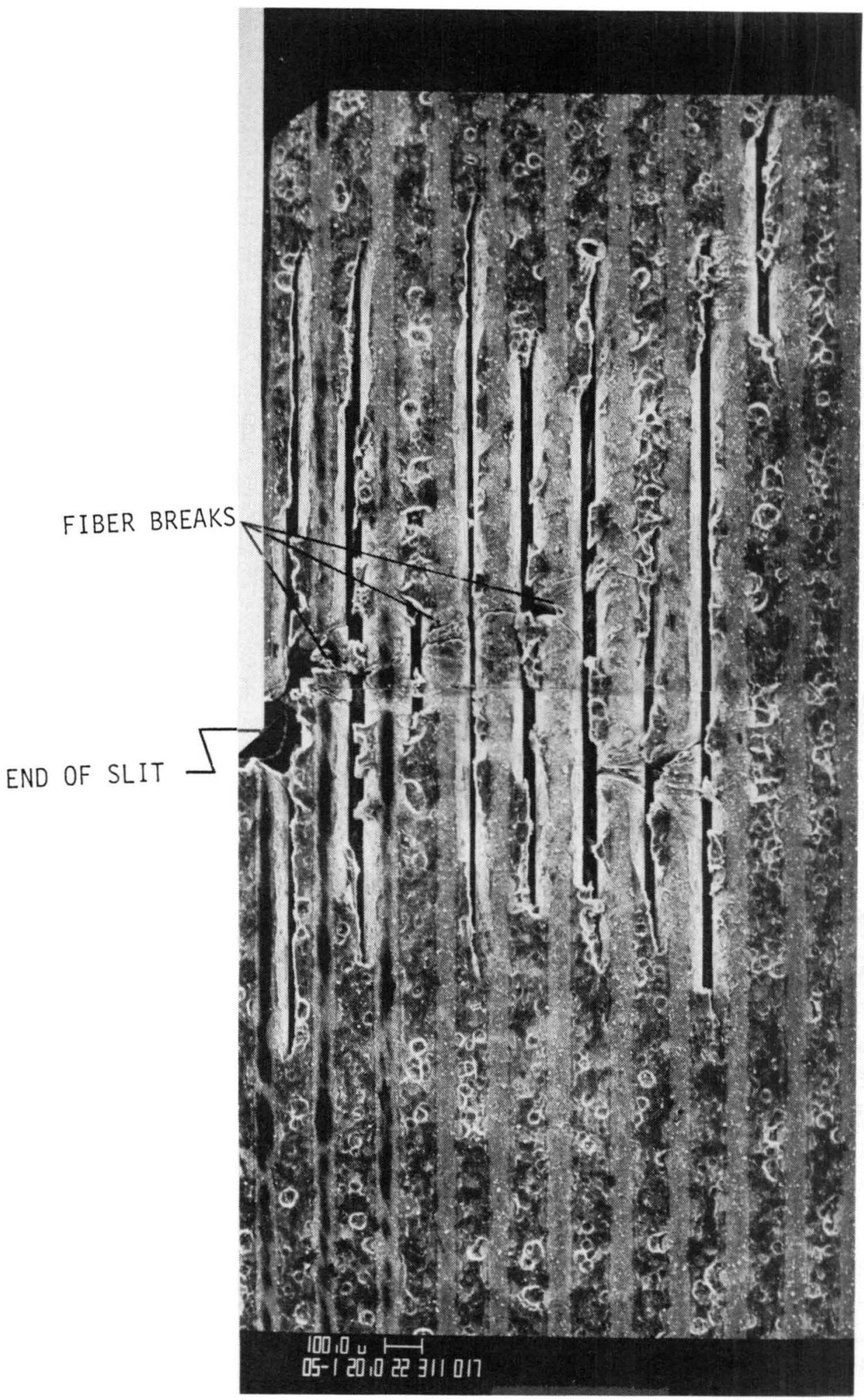

Fig. 10. $0^{\circ}$ fibers at end of slit of specimen 31012 fater fatiguing and with matrix partially removed. 

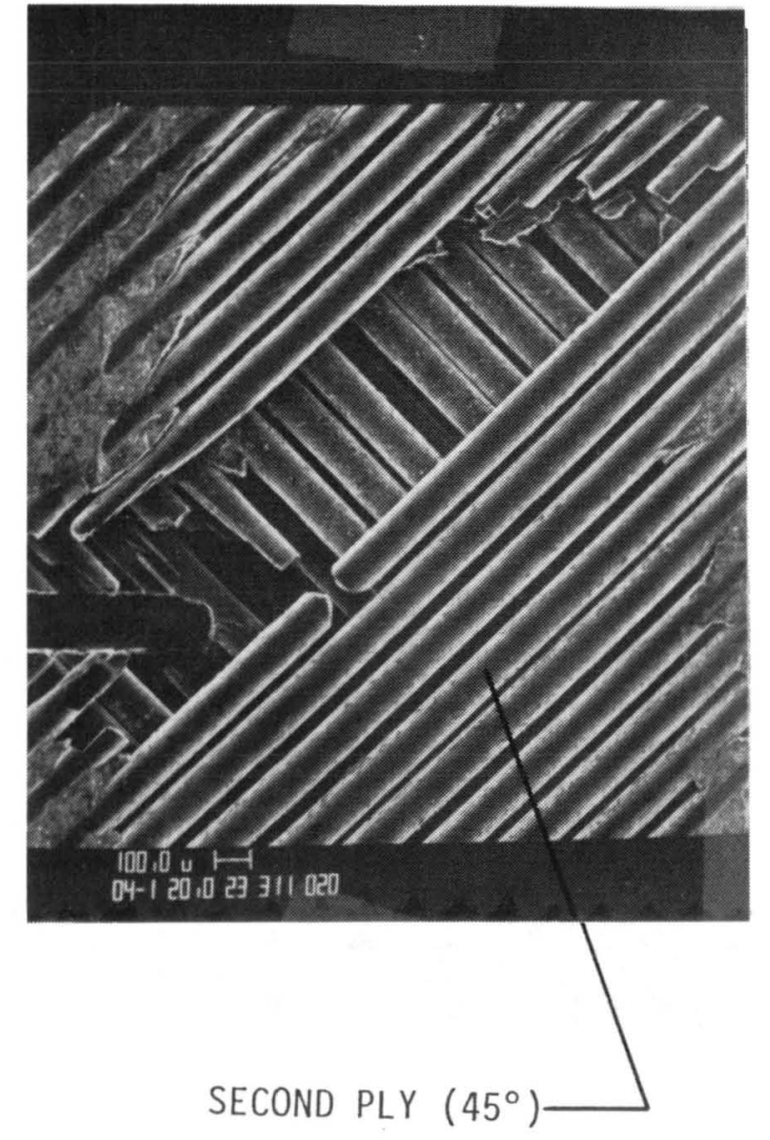

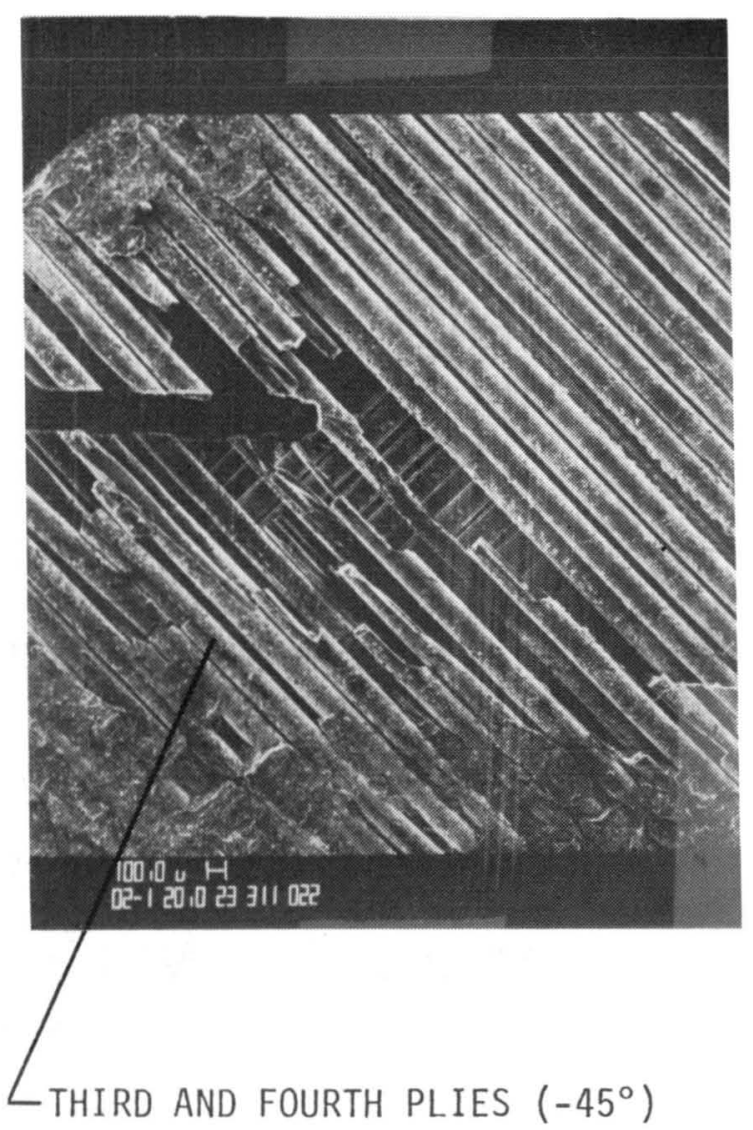

$\ddot{o}$

Fig. 11. Scanning electron micrograph of $45^{\circ}$ fibers at end of slit of specimen 31012 after fatiguing with matrix and overlying fibers removed. 


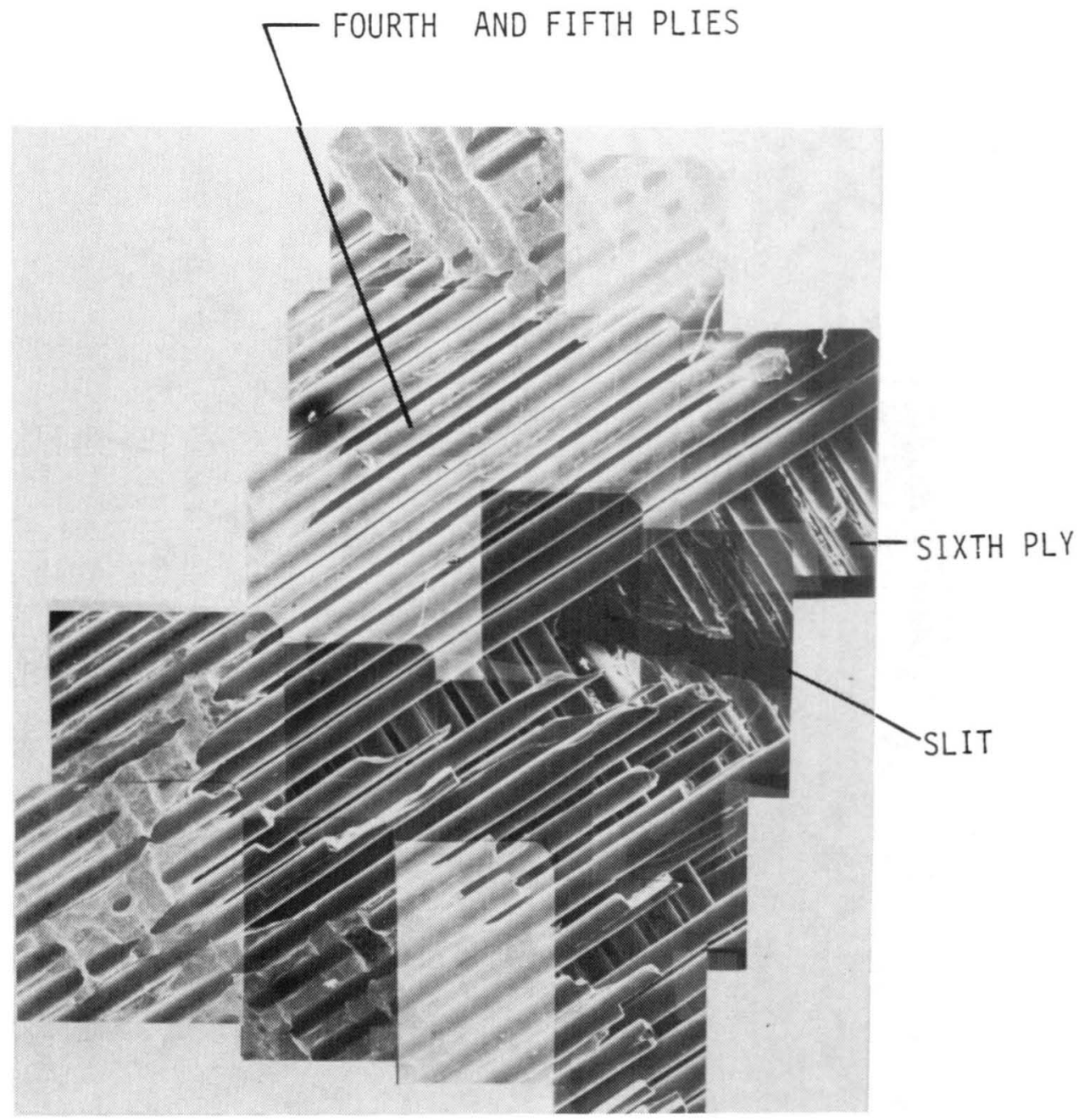

Fig. 12. Scanning electron micrograph of specimen 13013 showing 4th and 5 th plies $\left(45^{\circ}\right)$ and 6 th ply $\left(-45^{\circ}\right)$ at end of slit after fatiguing and with matrix removed. 


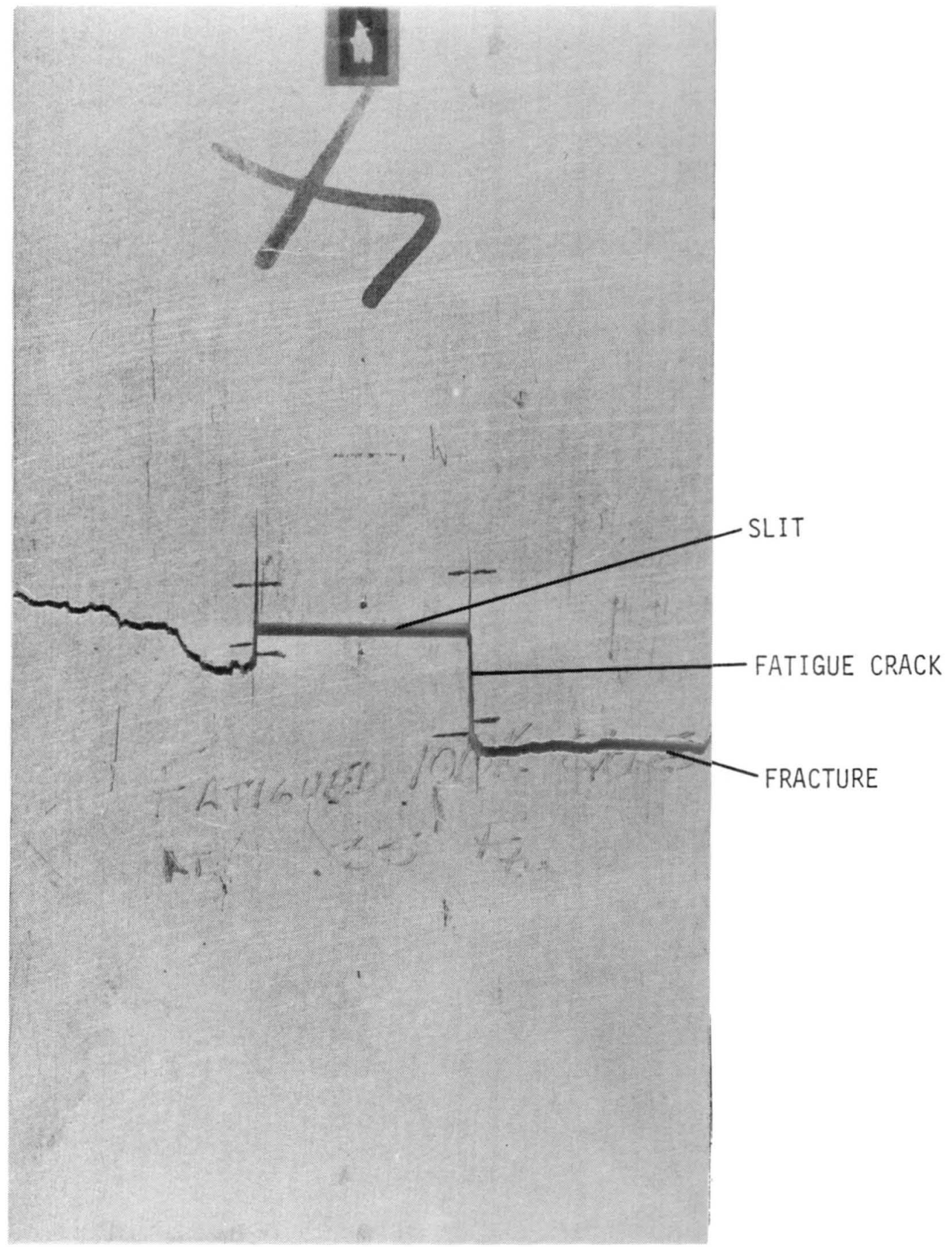

Fig. 13. Photograph of fatigued and fractured specimen 04022. 
SECTION A-A
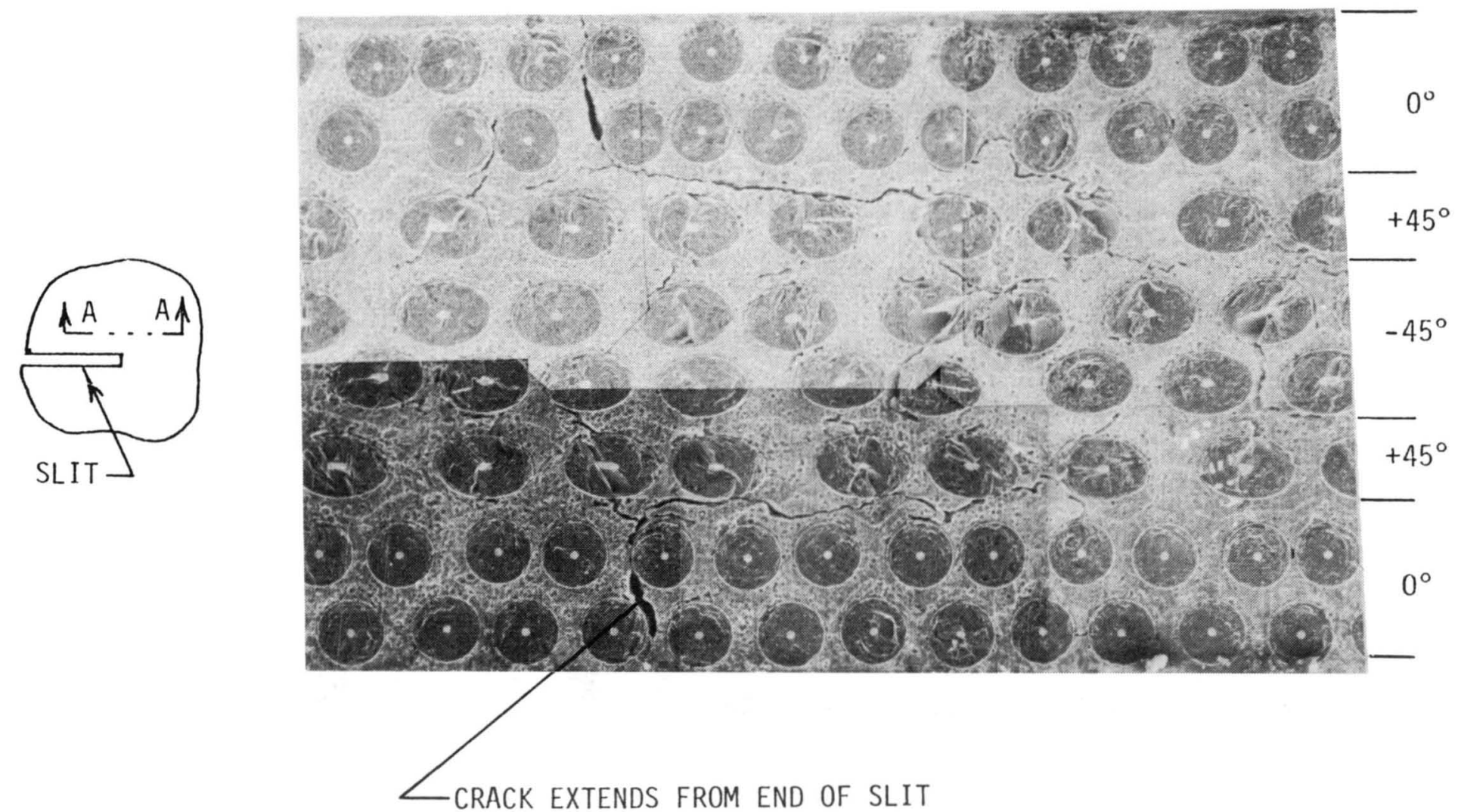

Fig. 14. Scanning electron micrograph of cross section of specimen, 43032 near end of slit after fatiguing. Specimen was etched with sodium hydroxide to enhance cracks in matrix. 
SECTION A-A

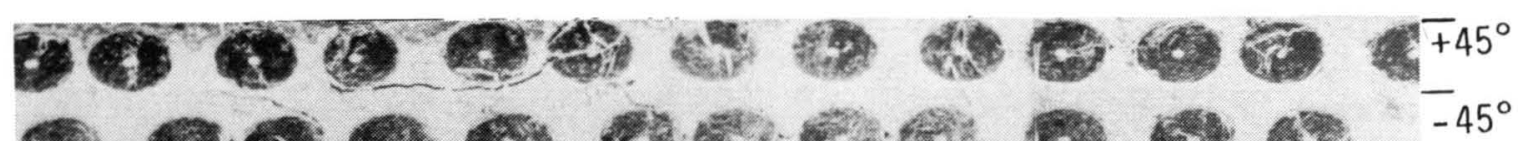

$\overbrace{\text { SLIT }}^{A}$

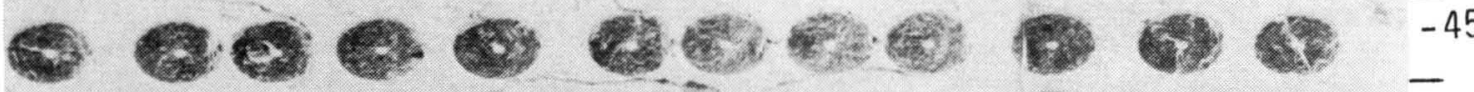

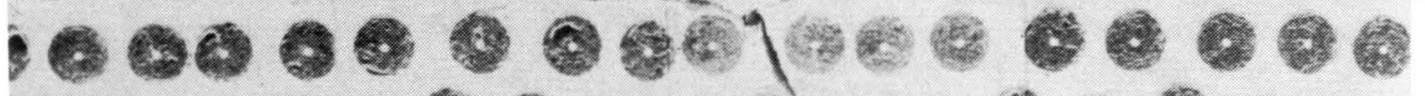

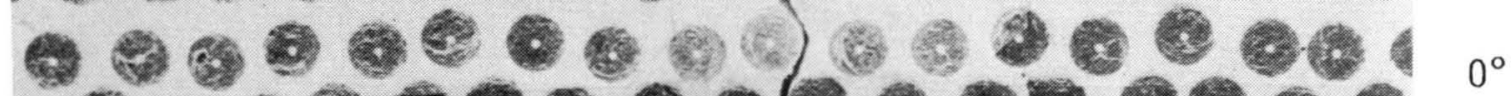

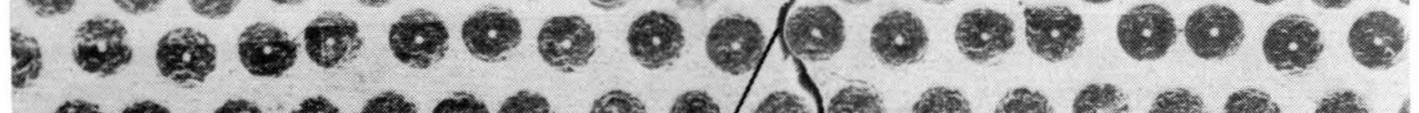

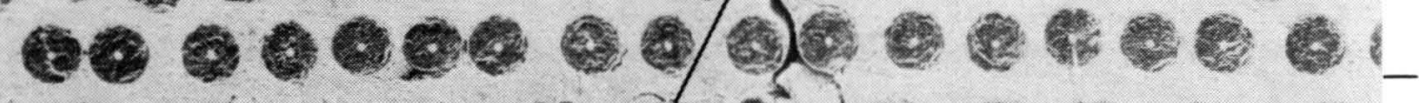

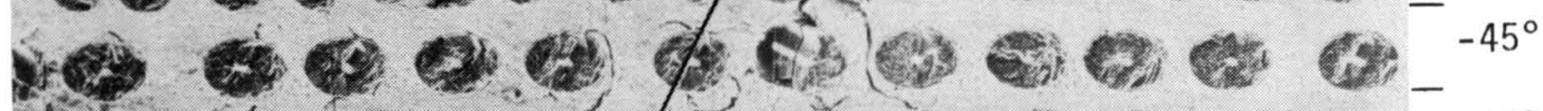

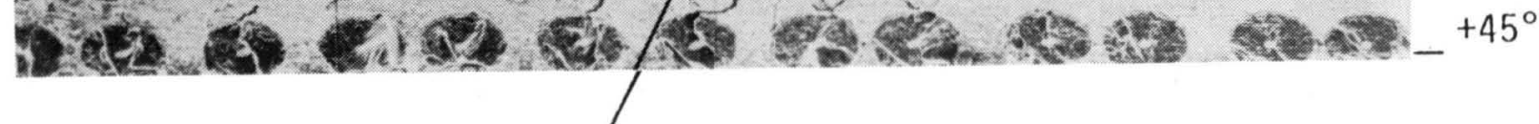

CRACK EXTENDS FROM END OF SLIT

Fig. 15. Scanning electron micrograph of cross section of specimen 58032 near end of slit after fatiguing. Specimen was etched with sodium hydroxide to enhance cracks in matrix. 


\section{SECTION A-A (TILTED TO SHOW SPECIMEN SURFACE)}
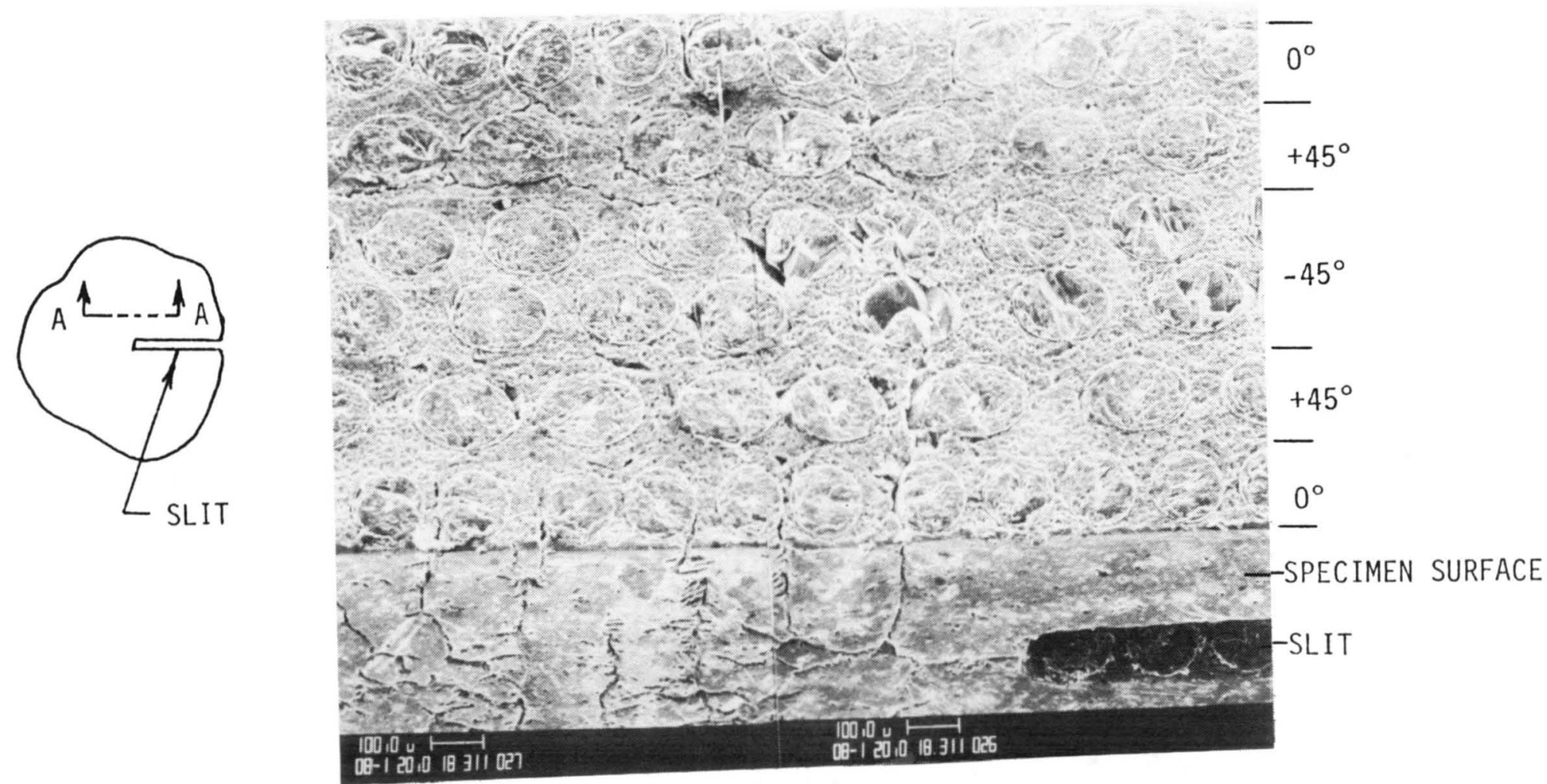

Fig. 16. Scanning electron micrograph of cross section of specimen 31012 in vicintiy of end of slit after fatiguing. Specimen was etched in sodium hydroxide to enhance matrix cracks. 




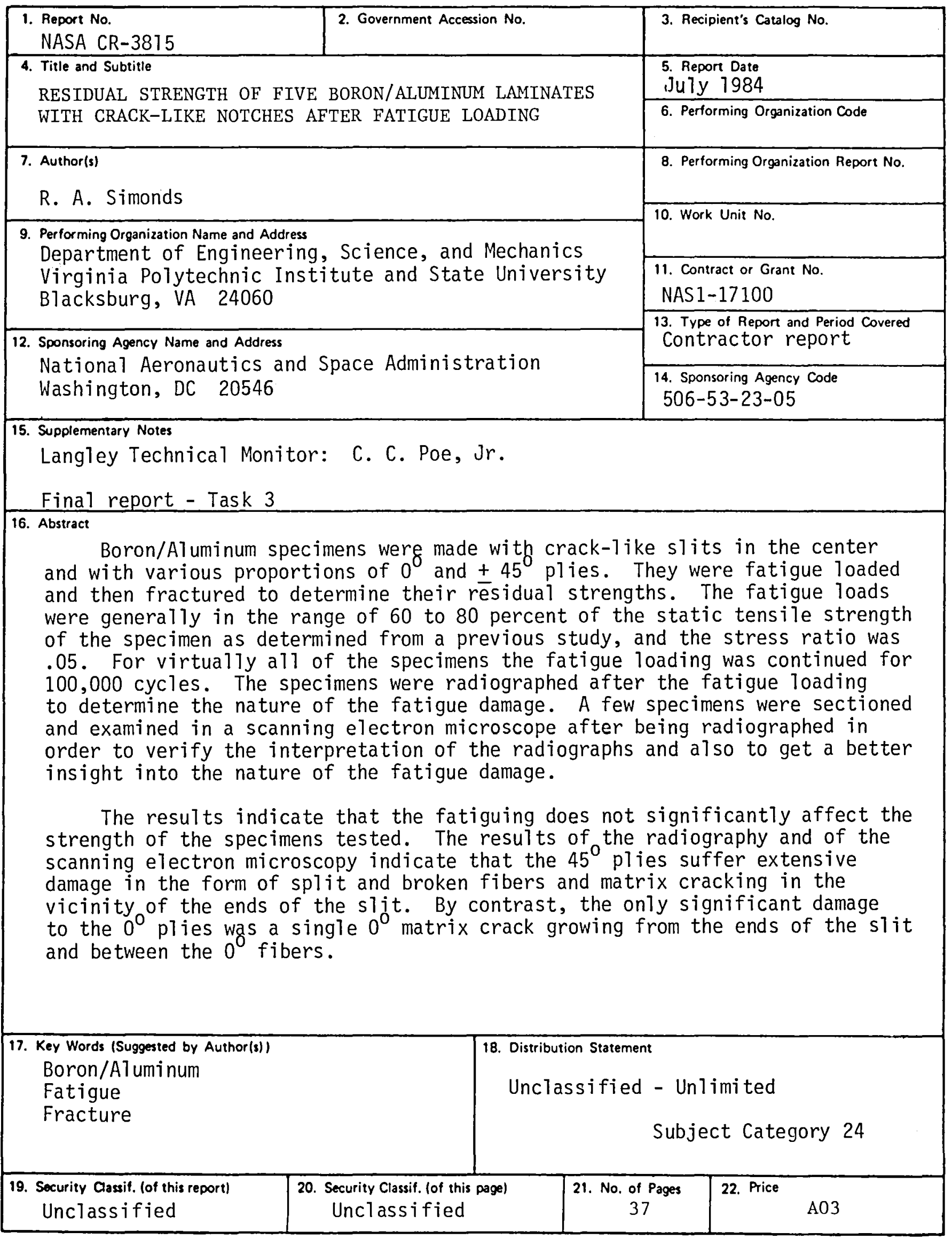



National Aeronautics and

Space Administration

Washington, D.C.

20546

Official Business

Penalty for Private Use, $\$ 300$
Postage and Feer Paid

National Aeronautics and

Space Administration

NASA-451

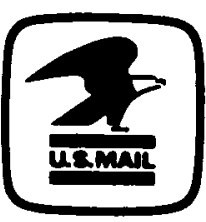

